\title{
Mistä yhteinen agenda keynesiläisille ja kasvukriitikoille?
}

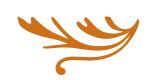

NiIN SANOTUT jälkikeynesiläiset talousajattelijat ja ekologisesta taloustieteestä inspiraatiota ammentavan kasvukriitikot ovat nousseet viime vuosina haastamaan talouspoliittista konsensusta sekä Suomessa että Euroopassa.

Kasvukriitikoiden mukaan ei ole realistista ajatella, että talouskasvu ja sen aiheuttamat ympäristöhaitat voitaisiin helposti kytkeä irti toisistaan. He esittävät vaatimuksia länsimaisen keskiluokan kulutuksen vähentämisestä, työajan lyhentämisestä sekä tulojen uudelleenjaosta vaurailta köyhemmille. Taloustutkija John Maynard Keynesin kannattajat taas korostavat, että rahataloudessa vallitsee pysyväluonteinen kysyntävaje, minkä takia julkisen vallan olisi talouspolitiikassa omaksuttava entistä suurempi vastuu kansantalouden korkeasta investointiasteesta.

Taloudessa tarvitaan jatkuvasti kysyntäpuolen toimia tulevaisuutta koskevan epävarmuuden hillitsemiseksi.

Keynesiläisiä ja kasvukriitikoita yhdistää kritiikki vallitsevaa kasvupolitiikkaa kohtaan, mutta ovatko heidän pyrkimyksensä sovitettavissa yhteen? Eivätkö keynesiläiset suosittele toimia investointi- ja kulutuskysynnän lisäämiseksi siinä missä kasvukriitikoiden kritiikki kohdistuu luontoa tuhoavaan kerskakulutukseen?

On totta, että jälkikeynesiläisen taloustieteen piirissä tuotannon ja kulutuksen ekologisin rajoitteisiin on kiinnitetty liian vähän huomiota. Muutaman vuoden takaisessa A New Guide to Post Keynesian Economics -kirjassa ympäristökysymyksille ei omistettu yhtään omaa lukua. Toisaalta kasvukriitikot puhuvat usein yltäkylläisyydestä ja kulutuksen vähentämisestä me-muodossa, vaikka myös OECD-maissa on suuri joukko ihmisiä, jotka kärsivät työttömyydestä ja köyhyydestä. Työllistävä kasvu olisi monien ihmisten etu.

Tulevaisuudessa keynesiläisten ja kasvukriitikoiden olisi joka tapauksessa pyrittävä aktiivisemmin rakentavaan vuoropuheluun ja etsittävä yhteisiä intressejä. Viime vuosina on otettu ensimmäisiä askelia tähän suuntaan. Keskustelussa "vihreästä keynesiläisyydestä" on nostettu yhä useammin esiin Keynesin tuotannon utooppisempi puoli. Hän visioi vuoden 1930 esseessään Economic Possibilities for our Grandchildren maailmaa sadan vuoden päästä eli vuonna 2030. Keynes oletti, että jos maailma säästyisi suursodilta, ja jos teknologian kehitys jatkuisi samaan malliin, "taloudellinen ongelma" voisi olla jo ratkennut 2030. Keynesin nimi liitetään usein kasvu- ja työllisyyspolitiikkaan, mutta hän ammensi ajattelussaan myös G. E Mooren moraalifilosofiasta, ja liikkui englantilaisen Bloomsbury Groupin boheemipiireissä.

\section{KOHTI KUUDEN TUNNIN TYÖPÄIVÄÄ}

Keynes hahmotteli, että ei-niin-kaukaisessa tulevaisuudessa ihmiset voisivat työskennellä ainoastaan 15 tuntia viikossa, sillä tuotannon tehokkuuden myötä taloudellinen vauraus edellyttäisi entistä pienempää työpanosta.

"Taloudellisen ongelman" ratkettua teknologisen kehityksen ja tuottavuuden kasvun myötä entistä useampi voisi keskittyä hyvään elämään, ystäviin, kulttuuriin ja taiteeseen. Ehkäpä keynesiläiset ja kasvukriitikot voisivat löytää yhteisen sävelen juuri Keynesin hyvän elämän edistämisen ja työajan lyhentämisen agendasta. Tätä tulkintaa on pitänyt viime vuosina esillä erityisesti Keynesin elämäkertasarjan laatija, lordi Robert Skidelsky, joka kirjoitti teoksen How Much is Enough?: The Love of Money, 
and the Case for the Good Life (2013) yhdessä poikansa Edwardin kanssa.

Mutta miksi Keynesin visio 15 tunnin työviikosta uhkaa jäädä utopian tasolle, vaikka vuoteen 2030 on enää reilut 15 vuotta? Robert Skidelskyn mukaan Keynesin virhe oli siinä oletuksessa, että taloudellinen yltäkylläisyys vähentäisi yksilöiden tarvetta rehkiä, kilpailla ja kasata rahavarallisuutta. Globaalissa ja eriarvoisessa taloudessa eurooppalaiset pelkäävät putoavansa kilpailussa Kiinan kelkasta ja keskiluokka pyrkii kulutustottumuksissaan jäljittelemään yhteiskuntien superrikkaita. Muutos kohti Keynesin "hyvän elämän politiikkaa " ja työajan lyhentämistä edellyttäisikin ennen muuta valtavaa kulttuurista muutosta.

Työajan lyhentämisen puolesta voidaan esittää nykyisessä maailmantilanteessa myös monta pragmaattista talouspoliittista argumenttia. Tuottavuuden kasvu OECD-maissa ei ole 1980-luvun jälkeen enää aiempaan tapaan mahdollistanut lyhyempiä työpäiviä ja pidempiä lomia. Suurin tarve työajan lyhentämiseen on Yhdysvalloissa, jossa teollisuuden duunareiden vuosityöaika on noin 1900 tuntia. Ranskassa duunarit rehkivät noin 1600 ja Suomessa reilu 1700 tuntia vuodessa.

Yhä useampi suomalainen toimihenkilö kokee, että lisääntynyt vapaa-aika lisäisi elämänlaatua palkankorotuksia enemmän. Toisaalta pienipalkkainen palvelualojen pätkätyöläinen saattaa arvostaa enemmän lisätyötunteja ja euromääräisiä palkankorotuksia.

\section{JULKISILLA INVESTOINTIOHJELMILLA EKOLOGISESTI KESTÄVÄÄ KASVUA?}

Keynesiläiset ja kasvukriitikot saattaisivat löytää yhteisiä intressejä myös julkisen sektorin aktiivisemmasta investointipolitiikasta.

Yksi jälkikeynesiläisen rahatalouden analyysin vahvuuksista on, että sen mukaan valtion julkisen kulutuksen ja investointien rajoitteet ovat hyvin erilaisia kuin yleisesti ymmärretään. Rahapoliittisesti suvereenin valtion - jonka maksusitoumukset on merkitty sen omassa valuutassa - kulutuksen rajoitteita ei aseta rahoitusmarkkinoiden halu ostaa valtionvelkakirjoja. Keskuspankin tuella valtio voi aina selvitä

\section{VISIO I 5 TUNNIN}

\section{TYÖVIIKOSTA UHKAA}

\section{J $\ddot{A A ̈ D} \ddot{A}$ UTOPIAN TASOLLE.}

maksuvelvoitteistaan, mutta sen kulutuksen rajoja määrittelevät kansantalouden ulkoinen tasapaino ja inflaatio. Pieni kansantalous tarvitsee elinvoimaisen vientisektorin, ja kustannusinflaatio voi lähteä kiihtymään jo ennen täystyöllisyyden saavuttamista.

Eurooppalaisen investointipolitiikan kannalta ongelmaksi on muodostunut, että euroalueen jäsenmaat ovat menettäneet yhteisvaluutan aikana rahapoliittisen suvereniteettinsa. Euroopan keskuspankilta on kielletty suora finanssipolitiikan rahoitus, toisin kuin Yhdysvalloissa. Jos poliittista tahtoa olisi, niin EU:lla ja ennen muuta euroalueella olisi mahdollisuus kääntää suunta säästöistä kohti Euroopan laajuista investointipolitiikkaa.

Jos ja kun tuotanto ja kulutus halutaan ohjata lähitulevaisuudessa vähäpäästöiseen ja hiilineutraaliin suuntaan, tarkoittaa se välttämättä massiivia julkisia investointeja koulutukseen, tietoyhteiskunnan infrastruktuuriin, energiatehokkuuteen ja uusiutuvaan energiaan.

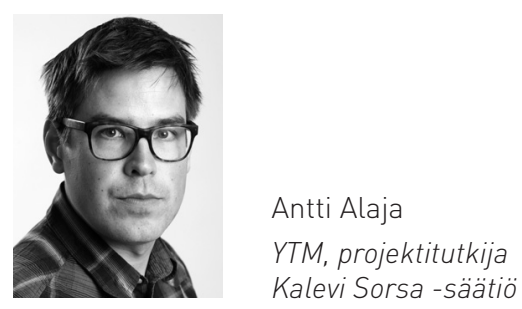

Antti Alaja on kirjoittanut yhdessä Esa Suomisen kanssa kirjan Taloutta työväelle. Markkinaliberalismin myyttejä murtamassa (Into-kustannus, 2013). 